\title{
„INFORMOWAL, WPROWADZAJĄC SZCZYPTE RODZINNOŚCI”. OMÓWIENIE CZASOPISMA „TEOLOGIA W POLSCE. BIULETYN INFORMACYJNY. DOKUMENTY, STUDIA, INFORMACJE” (1983-2006)
}

\begin{abstract}
Streszczenie
Czasopismo „Teologia w Polsce. Biuletyn Informacyjny. Dokumenty, Studia, Informacje" - wydawane było w latach 1983-2006 z inicjatywy o. Stanisława Celestyna Napiórkowskiego OFMConv i Karola Klauzy. W tym czasie stanowiło forum informacyjne i rodzaj komunikatora, początkowo między absolwentami Wydziału Teologicznego KUL i ich wykładowcami, a następnie ogółem polskich teologów. W artykule podjęto próbę odtworzenia historii powstania i funkcjonowania pisma, opisania jego struktury oraz analizy treści jego numerów.
\end{abstract}

Słowa kluczowe: „Teologia w Polsce”; teologia; czasopismo; Stanisław Celestyn Napiórkowski; Karol Klauza; Wydział Teologiił Katolicki Uniwersytet Lubelski; KUL

Celem artykułu jest opisanie powstania i funkcjonowania wydawanego w latach 1983-2006 pisma „Teologia w Polsce. Biuletyn Informacyjny. Dokumenty, Studia, Informacje" jako szczególnego rodzaju fenomenu wydawniczego. Podjęto tu próbę analizy treści wszystkich numerów od powstania pisma do momentu zmiany wydawcy i składu redakcji, a co za tym poszło - przekształcenia go z kwartalnika informacyjnego w półrocznik o profilu naukowym. Materiał badawczy obejmuje 86 numerów oraz trzy numery specjalne, zgromadzone w zasobach Biblioteki Uniwersyteckiej KUL oraz Biblioteki Narodowej. Postawione pytania

\footnotetext{
* Paulina Byzdra-Kusz - dr historii; adiunkt w Ośrodku Badań nad Dziejami KUL, Katolicki Uniwersytet Lubelski Jana Pawła II;

e-mail:pkusz@kul.pl

https://orcid.org/0000-0002-5495-5916
} 
badawcze dotyczą celu powstania pisma, jego struktury, wiodącej tematyki oraz postaci twórców i grupy odbiorów. W odtworzeniu historii „Teologii w Polsce” bardzo pomocne były relacje jej redaktorów. Jak dotąd periodyk nie doczekał się odrębnego naukowego opracowania, nie licząc leksykograficznego ujęcia w Encyklopedii 100-lecia KUL ${ }^{1}$.

\section{Powstanie czasopisma, twórcy i odbiorcy}

Pierwszy numer „Teologii w Polsce” ukazał się w listopadzie 1983 r. w Lublinie. W latach 1983-1989 pismo wychodziło nieregularnie, a od 1990 do $2006 \mathrm{r}$. - jako kwartalnik. Od numeru 65 z 2001 r. brak już drugiego członu podtytułu: „Dokumenty, Studia, Informacje”. Łącznie w analizowanym okresie ukazało się 86 numerów, do których należy doliczyć trzy specjalne ${ }^{2}$. Podkreślić należy, że czasopismo powstało i było tworzone na Katolickim Uniwersytecie Lubelskim. Jego pomysłodawcą był młody pracownik naukowy - dr Karol Klauza ${ }^{3}$. Początkowo miał być to organ łączący wykładowców teologii dogmatycznej i ich absolwentów. Ideę poparł i zaangażował się w nią wykładowca i świeżo upieczony profesor KUL, o. Stanisław Celestyn Napiórkowski OFMConv ${ }^{4}$. W latach osiem-

${ }^{1}$ M. Fijołek, ,,Teologia w Polsce”, w: Encyklopedia 100-lecia KUL, t. 2, red. E. Gigilewicz, Lublin 2018, s. 471-472.

${ }^{2}$ Pierwszy, zawierający przedruki zagranicznych artykułów na temat teologii środków przekazu, opublikowano między numerami 14 i 15 z 1987 r.; drugi, z przedrukiem tekstu Literatura a teologia autorstwa Czesława Ryszki - między 17 i 18 z 1988 r.; trzeci, zatytułowany „Być Teologiem - Być Kościołem”, ukazał się zaś w 1994 r. pomiędzy numerami 39 i 40.

${ }^{3}$ Karol Klauza (ur. w 1947 r. w Szczecinie) - studia z filozofii i teologii odbył w Krakowie, Warszawie i na Uniwersytecie Gregoriańskim w Rzymie; magisterium, licencjat i doktorat z teologii dogmatycznej uzyskał na Wydziale Teologii KUL. Kkontynuował studia na Katolickim Uniwersytecie w Louvain-la-Neuve w Belgii. Specjalista z zakresu metodologii teologicznej, ikonologii i teologii komunikowania. Habilitował się w 2002 r. Wieloletni kierownik Katedry Teologii Ikony. Należy do licznych zespołów redakcyjnych czasopism i serii naukowych, oprócz „Teologii w Polsce” m.in. „Roczników Teologicznych”, z. 2: „Dogmatyka”, „Ethosu”, „Niedzieli”, „Biuletynu Edukacji Medialnej”. Pracował także przy systemie informacyjnym „Opoka”. W redakcji „Teologii w Polsce" zajmował się adiustacją i kolportażem.

${ }^{4}$ Relacja Stanisława Celestyna Napiórkowskiego OFMConv z 18 kwietnia 2020 r.; relacja Karola Klauzy z 17 kwietnia 2020 r.

Stanisław Celestyn Napiórkowski OFMConv (ur. 1933 r. we wsi Mroczki Małe) - w 1954 r. złożył śluby wieczyste w Zakonie Franciszkanów Konwentualnych, a w 1957 r. przyjął święcenia kapłańskie. Ukończył studia na Sekcji Teologii Dogmatycznej na Wydziale Teologii KUL. W 1961 r. uzyskał licencjat i magisterium, w 1965 - doktorat teologii dogmatycznej pod kierunkiem o. prof. Andrzeja Krupy. W 1974 r. habilitował się, w 1983 został profesorem nadzwyczajnym, a w 1989 profesorem zwyczajnym na Wydziale Filozofii Chrześcijańskiej KUL. Przez dwadzieścia lat kierownik Katedry Mariologii KUL. Był także stałym współpracownikiem Instytutu Ekumenicznego tej uczelni, profesorem teologii dogmatycznej w Wyższym Seminarium Duchownym Ojców Franciszkanów w Łodzi-Łagiewnikach. Opublikował ponad 600 prac naukowych, wiele podręczników i książek. Obecnie na emeryturze. 
dziesiątych istniało wprawdzie w Polsce niemało pism teologicznych ${ }^{5}$, jednak były to wyłącznie periodyki naukowe, często o wąskiej specjalizacji tematycznej lub ograniczone do lokalnego środowiska. Brakowało w nich zatem miejsca na szeroko rozumiane informacje ze świata teologii, od konferencji począwszy, na nowych publikacjach skończywszy.

We wstępie do pierwszego numeru „Teologii w Polsce” przedstawiono cel i okoliczności powstania periodyku. Czytamy tam, że zaistniał on dzięki

szeregowi sprzyjających uwarunkowań zewnętrznych, uświadomionej potrzebie tego typu wydawnictw oraz życzliwości i ofiarności osób, którym sprawa dokumentowania polskiego dorobku teologicznego leży głęboko na sercu'

Jedną z najważniejszych ról, jakie miał do odegrania, była integracja środowisk teologicznych, prezentacje dokonań najbardziej prestiżowych ośrodków naukowych w Polsce oraz wymiana indywidualnych doświadczeń badaczy. Podtytuł wyraźnie wskazuje, że zamiarem redakcji było stworzenie platformy wymiany informacji i studiów na temat przeszłości, teraźniejszości i przyszłości teologii w Polsce. Ze słowa wstępnego dowiadujemy się, że kładziono nacisk na teologię systematyczną, lecz jednocześnie wyrażono nadzieję, że pismo będzie dokumentować także inne działy teologii, np. fundamentalną czy praktyczną. Jak wskazuje analiza wszystkich numerów, ostatecznie nie ukazywały się w nich takie treści. Pismo pełniło funkcję informacyjną dla wykładowców, studentów i duszpasterzy w kraju i za granicą, powiadamiając o rozwoju tej dziedziny w Polsce. Pomyślane zostało również jako przestrzeń dla bieżącej polemiki między teologami. O. Stanisław Celestyn Napiórkowski wielokrotnie podkreślał potrzebę istnienia forum, na którym teologowie mogliby się spotykać i prezentować swoje publikacje, dzięki czemu wyniki ich badań dotarłyby do szerszego grona odbiorców?

Dzięki konkretnie sprecyzowanym celom, które przyświecały redaktorom czasopisma, jasno określono jego odbiorców. Zarówno w założeniu, jak i w praktyce „Teologia w Polsce” była pismem nie tylko dla duchownych, ale i świeckich. Często podkreślano tam rolę tych ostatnich w Kościele katolickim i wkład w roz-

${ }^{5}$ Należy tu wymienić: „Collectanea Theologica” (prestiżowe przedwojenne pismo wznowione w 1949), „Rocznik Teologiczny” (wznowiony w 1959), „Studia Warmińskie” (od 1964), „Śląskie Studia Historyczno-Teologiczne” (od 1968), „Analecta Cracoviensia” (od 1969), „Studia Claromontana” (od 1981), polską wersję dwumiesięcznika „Communio” (od 1981) oraz „Studia i Dokumenty Ekumeniczne” (od 1983). Nie można też zapominać o pismach KUL: „Rocznikach Teologiczno-Kanonicznych", które po raz pierwszy wydano w 1949 r., oraz specjalizującym się w antyku chrześcijańskim „Vox Patrum” (od 1981).

${ }^{6}$ Stowo wstepne, „Teologia w Polsce” (dalej: TwP), 1 (1983) nr 1, s. 2.

${ }^{7}$ Relacja Stanisława Celestyna Napiórkowskiego OFMConv z 18 kwietnia 2020 r. 
wój teologii, odnotowując ich naukowe sukcesy ${ }^{8}$. Przede wszystkim jednak pismo ukazywało się pod auspicjami Sekcji Dogmatycznej Teologów Polskich?

Jak pisał o. Celestyn Napiórkowski:

To agora Sekcji Dogmatycznej Teologów Polskich, przede wszystkim rzymskokatolickich, których jest niemały tłum - prawie półtorej setki. Niejasności w tylu i takich głowach to nie drobiazg; należy [je] światłem prawdy rozpraszać $^{10}$.

Niewątpliwie sympozja i zjazdy Sekcji, na których obecni byli również absolwenci, były okazją do docierania do odbiorców i kolportażu czasopisma ${ }^{11}$.

W latach dziewięćdziesiątych i pierwszej dekadzie XXI wieku z „Teologią w Polsce" związane było Koło Naukowe Teologów KUL. Jego członkowie pisywali teksty i sprawozdania oraz współpracowali z redakcją, ta natomiast starała się na swoich łamach reklamować tę organizację. Wynikało to przede wszystkim z głębokiego przeświadczenia o. Celestyna Napiórkowskiego, że młodych adeptów teologii należy formować i nauczyć współpracy. Uważał, że tej ważnej umiejętności brakuje wielu ludziom, także naukowcom ${ }^{12}$.

Przez pierwsze osiem lat funkcjonowania pisma (1983-1991) redakcję tworzyli: Stanisław Celestyn Napiórkowski OFMConv, Karol Klauza oraz ks. Ryszard Szmydki OMI ${ }^{13}$, jednak główny ciężar pracy spoczywał na dwóch pierwszych. W numerze 28 z 1991 r. ukazała się informacja, że grono to opuści ks. Szmydki, ponieważ odchodzi z KUL, by pracować jako duszpasterz w jednym z krajów powstających na gruzach Związku Sowieckiego ${ }^{14}$. Zarówno na KUL, jak

${ }^{8} \mathrm{~W}$ notatce Pierwszy w Polsce świecki profesor teologii katolickiej z numeru 56 z 1999 r. czytamy o dr. hab. Michale Wojciechowskim, a w jednym z wcześniejszych odnotowano, że był on też pierwszym w Polsce doktorem habilitowanym $\mathrm{z}$ tej dziedziny, który nie należał do stanu duchownego.

${ }^{9}$ Relacja Anny Faszczowej z 20 kwietnia 2020 r. W latach 80. kierownictwo Sekcji spoczywało w rękach ks. Andrzeja Zuberbiera (przewodniczącego), ks. Alfonsa Nossola (zastępcy przewodniczącego), o. Jacka Salija OP (sekretarza i skarbnika). Przytoczmy notatkę powstałą w 1986 r., a opublikowaną prawie dwadzieścia lat później: „W 1984 r. [powinno być: 1983] zaczęliśmy wydawać najprostszą techniką »Biuletyn Teologia w Polsce. Dokumenty. Studia. Informacje« (...) Publikujemy dokumenty, informacje i studia dotyczące historii, stanu obecnego, perpektyw teologii systematycznej i pastoralnej w Polsce. Informujemy się nawzajem, co robimy. Mamy własne forum: biedne, ale funkcjonalne". Sekcja Dogmatyczna Teologów Polskich 1983-1986 (kartki znalezione w zgliszczach), TwP, 20 (2002) nr 67, s. 43-44.

${ }^{10}$ S.C. Napiórkowski, Prawostawna apokatastaza?, TwP, 15 (1997) nr 49, s. 73.

${ }^{11}$ Relacja Karola Klauzy z 17 kwietnia 2020 r.

${ }^{12}$ Relacja Anny Faszczowej z 20 kwietnia 2020 r.

${ }^{13}$ Ks. Ryszard Szmydki OMI (ur. w 1951 r. w Terebiskach) - w 1970 r. wstąpił do Zgromadzenia Misjonarzy Oblatów Maryi Niepokalanej. W 1978 r. otrzymał święcenia kapłańskie. Studiował na Papieskim Uniwersytecie Gregoriańskim i Katolickim Uniwersytecie Lubelskim. W 2010-2016 był prowincjałem Polskiej Prowincji Misjonarzy Oblatów Maryi Niepokalanej. W 2014 r. został mianowany sekretarzem generalnym Papieskiego Dzieła Rozkrzewiania Wiary w Kongregacji Ewangelizacji Narodów w Rzymie. Trzy lata później objął stanowisko podsekretarza Kongregacji Ewangelizacji Narodów.

${ }^{14}$ TwP, 9 (1991) nr 28, s. 48. 
i w redakcji na krótko zastąpił go o. Zdzisław Kijas OFMConv ${ }^{15}$. Przez kolejne osiem numerów kwartalnik prowadzili o. Celestyn Napiórkowski i Karol Klauza. Od numeru 39 drugiego z nich zastąpił ks. Krzysztof Kowalik SDB ${ }^{16}$, który pozostał w piśmie przez kolejne 24 numery, z krótką przerwą podczas prac nad numerem 60, gdy o. Celestynowi Napiórkowskiemu partnerowali Adam Jarząbek $^{17}$ i Piotr Szelest ${ }^{18}$. Oni też zastąpili ks. K. Kowalika SDB, gdy po 64 numerze odszedł z redakcji. Od numeru 71 (2003) do końca wydawania czasopisma $\mathrm{w}$ formie biuletynu informacyjnego w stopce redakcyjnej widnieje nazwisko Anny Kulczyckiej ${ }^{19}$. Pomocą służyła jednak pismu już od roku $2000^{20}$. Przy numerze 44 w 1995 r. odnotowano nazwisko ks. Andrzeja Czai ${ }^{21}$. W stopce redakcyjnej nigdy nie było podziału na redaktora naczelnego, prowadzącego i sekretarza, lecz prym wiódł o. Celestyn Napiórkowski. Na nim też spoczywała większość obowiązków redakcyjnych, na czele z pozyskiwaniem materiałów, które zresztą trafiały do

${ }^{15}$ Pracował przy numerach 29 i 30 w 1992 r. Zdzisław Kijas OFMConv (ur. w 1960 r. w Pewli Ślemieńskiej) - święcenia kapłańskie przyjął w 1986 r. z rąk Jana Pawła II. W 1990 r. uzyskał doktorat z teologii dogmatycznej i nauk religijnych na Uniwersytecie Katolickim w Louvain-La-Neuve. W latach 1991-1993 pracował w Katedrze Mariologii KUL. Po habilitacji w 1996 r. podjął studia na Uniwersytecie św. Bonawentury w Nowym Jorku i uzyskał tam stopień Master of Arts z nauk humanistycznych. Dziekan Papieskiego Wydziału Teologicznego św. Bonawentury Seraficum w Rzymie, nauczyciel akademicki Wydziału Teologicznego Uniwersytetu Papieskiego Jana Pawła II. Od 2010 r. relator Kongregacji Spraw Kanonizacyjnych.

${ }^{16}$ Krzysztof Kowalik (ur. 1959 r.) - doktorat pod kierunkiem o. S.C. Napiórkowskiego uzyskał w 1994 r. Habilitował się w 2003 r. Był pracownikiem naukowym KUL. Obecnie zatrudniony na Politechnice Opolskiej.

${ }^{17}$ Adam Jarząbek (ur. 1971 r. w Kielcach) - w latach 1992-1997 studiował na Wydziale Teologii KUL. W czasie studiów prezes Koła Naukowego Teologów KUL. Obronił pracę magisterską z teologii dogmatycznej, której promotorem był o. S.C. Napiórkowski. W latach 1997-2010 pracował jako katecheta w Sandomierzu i Lublinie. Studia doktoranckie na Wydziale Teologii KUL odbył w latach 1998-2002. Współredaktor Kalendarza Ekumenicznego przez trzy jego edycje od roku 2000. Od 2013 r. pilot wycieczek i muzyk (duet Jarząbek-Jurkiewicz).

${ }^{18}$ Piotr Szelest (ur. 1973 r. w Rabce-Zdroju) - w latach 1992-1997 odbył studia magisterskie na Wydziale Teologii KUL, tam też w 2007 r. obronił pracę doktorską, obecnie kierownik Działu Administracji Domami Studenckimi KUL.

${ }^{19}$ Anna Maria Faszczowa, z domu Kulczycka (ur. 1977 r. w Lubaczowie) - w latach 1996-2001 odbyła studia magisterskie na Wydziale Teologii, następnie w 2004 obroniła doktorat z dogmatyki (obie prace pod kierunkiem o. S.C. Napiórkowskiego), obecnie redaktorka kilku pism formacyjnych, animatorka chóru liturgicznego w Horyńcu Zdroju. Po zaprzestaniu ukazywania się pisma osobiście zajęła się przekazaniem wszystkich numerów „Teologii w Polsce” Bibliotece Narodowej. W tym celu zebrała dublety lub skopiowała prywatne egzemplarze o. S.C. Napiórkowskiego, zszyła je i przewiozła do Warszawy.

${ }^{20}$ Relacja Anny Faszczowej z 20 kwietnia 2020 r.

${ }^{21}$ Ks. Andrzej Czaja (ur. 1963 r. w Oleśnie) - przyjął święcenia w 1988 r., w latach 1989-1993 odbył studia w zakresie teologii dogmatycznej w KUL, a rok później obronił doktorat. W latach 1996-1998 przebywał na stypendium naukowym w Ekumenicznym Instytucie Johanna Adama Möhlera w Paderborn, gdzie przygotowywał rozprawę habilitacyjną. Habilitację uzyskał w 2003 r. Od 1993 r. pracownik naukowy KUL, współautor reformy studiów teologicznych oraz podręcznika akademickiego teologii dogmatycznej. Od 2009 r. biskup ordynariusz diecezji opolskiej. 
niego w sposób naturalny z racji sprawowanej funkcji ${ }^{22}$. Redakcja mieściła się w konwikcie księży studentów przy ul. Marcelego Nowotki 7 w Lublinie, w 1990 r. przemianowanej na ul. ks. Idziego Radziszewskiego.

Analiza autorstwa artykułów opublikowanych w 86 numerach „,Teologii w Polsce" wskazuje, że 59 z 82 publikujących tam osób miało związki z KUL - byli albo absolwentami studiów magisterskich i doktoranckich na Wydziale Teologicznym, albo pracownikami uczelni, zatrudnionymi na Wydziale Teologii oraz w Międzywydziałowym Zakładzie Leksykografii ${ }^{23}$. Oznacza to, że 71 proc. autorów miało związki z KUL. W „Teologii w Polsce” publikowali najczęściej następujący pracownicy Wydziału Teologicznego: o. Stanisław Celestyn Napiórkowski OFMConv, ks. Ryszard Szmydki OMI, ks. Jan Sergiusz Gajek MIC, ks. Czesław Bartnik, s. Ewa Durlak OSU, bp Jan Śrutwa, ks. Jerzy Misiurek, ks. Wacław Hryniewicz OMI, ks. Włodzimierz Sedlak, ks. Jerzy Szymik, ks. Jan Szczurek, ks. Krzysztof Góźdź, Elżbieta Adamiak i Karol Klauza. Pismo było więc ściśle związane z uczelnią, lecz na jego łamach gościły także takie osobistości polskiej nauki teologicznej jak: ks. Kazimierz Baran SJ, ks. Ignacy Bokwa, ks. Jacek Bolewski SJ, ks. Paweł Czyż, ks. Piotr Jaskóła, kard. Franciszek Macharski, ks. Andrzej Perzyński, ks. Józef Warzeszak, ks. Andrzej Zuberbier.

\section{Szata graficzna i naklad}

Przez ponad 23 lata układ pisma nie zmienił się prawie wcale. Czasopismo przyjęło format $\mathrm{A} 4$. Nie miało okładki, a pierwszą stronę stanowiła karta tytułowa z rzucającą się w oczy winietą na około jedną trzecią wysokości łamu, która była znakiem rozpoznawczym „Biuletynu Informacyjnego” przez cały okres jego wydawania. Zawierała pełen tytuł czasopisma: pierwszy człon, TEOLOGIA W POL$S C E$, wypisany był wersalikami i wyraźnie wyróżniał się wielkością; pozostałe człony miały ten sam krój pisma, jednak zapisywano je małymi literami: biuletyn informacyjny oraz dokumenty, studia, informacje. Pod winietą znajdował się spis treści, a u dołu strony - rok wydania oraz nazwa wydawcy: Sekcja Dogmatyczna Teologów Polskich. W prawym górnym rogu karty tytułowej umieszczano numer zeszytu, a do 2000 r. także skrót $T w P$ - oba elementy otoczone konturem granic Polski. Początkowo periodyk, łącznie z kartą tytułową, był czarno-biały. Od $1993 \mathrm{r}$. winieta miała kolor zielony, z krótką przerwą na odcień malinowy w latach 20002001. Innych elementów graficznych było niewiele - ograniczały się do nielicznych ilustracji, okładek prezentowanych książek oraz zdjęć doktorantów i autorów. Skromna szata graficzna była wynikiem nienajlepszej sytuacji finansowej pisma, które, co trzeba podkreślić, było wydawane wyłącznie wysiłkiem o. S.C. Napiórkowskiego i sympatyków ${ }^{24}$. Materiały prezentowane w czasopiśmie aż do 2000 r. redaktor naczelny przygotowywał własnoręcznie. Na karty A4 naklejał maszynopisy artykułów, sprawozdań czy też innych dokumentów, oryginalne

${ }^{22}$ Relacja Anny Faszczowej z 20 kwietnia 2020 r.

${ }^{23}$ Dane na podstawie teczek osobowych przechowywanych w Archiwum Uniwersyteckim KUL w zespołach: Referat Personalny, Akta osobowe studentów.

${ }^{24}$ TwP, 18 (2000) nr 61, s. 79. Relacja Anny Faszczowej z 20 kwietnia 2020 r. 
listy od czytelników oraz kopie okładek i spisów treści promowanych książek. Następnie egzemplarz wysyłał do Wyższego Seminarium Duchownego oo. Franciszkanów w Łodzi-Łagiewnikach ${ }^{25}$, gdzie był powielany ${ }^{26}$.

Gdy do powszechnego użytku weszły komputery, o. S.C. Napiórkowski postanowił przejść na „montaż elektroniczny”. W numerze 60 z 2000 r. spotykamy wprawdzie informację, że prace te powierzono Wydawnictwu oo. Franciszkanów „Bratni Zew” z Krakowa, jednak w praktyce zajmowali się tym doktoranci o. S.C. Napiórkowskiego, należący jednocześnie do Koła Naukowego Teologów KUL: Adam Jarząbek, Piotr Szelest oraz Anna Kulczycka. To właśnie ta ostatnia była dla redaktora naczelnego szczególną podporą: po otrzymaniu materiałów do danego numeru składała je w komputerowym edytorze tekstu, wklejając skany w pola tekstowe lub przepisując maszynopisy do pliku. W 2000 r. uporządkowała spis treści oraz przestrzeń czasopisma, zapoczątkowując podział w jego wnętrzu na stopkę i żywą paginę (początkowo w żywej paginie umieszczono tytuł czasopisma, a w stopce numery stron). Jak wspomina redaktorka:

ojciec Napiórkowski początkowo bronił się przed takimi zmianami w piśmie, obawiając się, że utraci ono swój swojski klimat i będzie za bardzo poukładane. W końcu jednak dał się przekonaće ${ }^{27}$.

Od tego czasu stosowano dwie kolumny w działach Sprawozdania, Doktoraty, Habilitacje, Artykuty oraz Nowości wydawnicze. Karty tytułowe były odtąd sztywniejsze, a od podwójnego numeru 68/69 w żywej paginie znalazła się nazwa działu, w stopce zaś tytuł czasopisma wraz z jego bieżącą numeracją oraz numery stron. O. Celestyn Napiórkowski potwierdził na łamach pisma, że przeszło ono na wyższy poziom techniczny, ale w ślad za tym wzrosły koszty ${ }^{28}$.

Tak przygotowany numer wysyłany był do Wydawnictwa i Drukarni oo. Franciszkanów w Niepokalanowie ${ }^{29}$, gdzie drukowano go i przekazywano do Lublina. Wówczas redaktor naczelny kolportował pismo pocztą do osób prywatnych oraz bibliotek wyższych seminariów duchownych ${ }^{30}$, licząc na datki, z którymi szczególnie zwlekały biblioteki WSD ${ }^{31}$.

${ }^{25}$ Drukowane były tam numery 1-43 (1983-1995).

${ }^{26}$ Relacja Anny Faszczowej z 20 kwietnia 2020 r.

${ }^{27}$ Tamże.

${ }^{28}$ TwP, 18 (2000) nr 61, s. 79. O. Napiórkowski zapewne chciał wypłacić Annie Kulczyckiej wynagrodzenie, ponieważ z powodu niekorzystnej sytuacji finansowej pisma wykonywała ona swoją pracę na zasadzie wolontariatu.

${ }^{29}$ Drukowane były tam numery 44-86 (1995-2006).

${ }^{30}$ Relacja Anny Faszczowej z 20 kwietnia 2020 r.; relacja o. Stanisława Celestyna Napiórkowskiego OFM Conv. z 18 kwietnia $2020 \mathrm{r}$.

${ }^{31}$ O. Napiórkowski szczególnie utyskiwał na taki stan rzeczy w numerze 44, jednak po wpłacie szczecińskiego seminarium z właściwym sobie humorem dodał: „Niechaj sczeźnie język, który łże, mówiąc, iż wszystkie Biblioteki WSD nie pamiętają (ekonomicznie) o TwP! Niektóre jednak pamiętają". TwP, 13 (1995) nr 44, s. 40. W kolejnej dekadzie ta finansowa bolączka jednak nie zniknęła, o czym świadczy wpis Ojca Profesora: „Pozostał problem bibliotek, których »poczuwa się« może 10\%”. TwP, 20 (2002) nr 67, s. 88. 
Nakład czasopisma nie był stały. Zwykłe numery wydawano w liczbie 200420 egzemplarzy, a specjalne lub tematyczne drukowane były nawet po 500, 600 czy 1000 sztuk. Największy nakład miał tom pt. Abym uwierzyt, zawierający przedruki wykładów z teologii dogmatycznej ks. Władysława Łydki ${ }^{32}$, ucznia Sługi Bożego ks. Wincentego Granata. Objętość poszczególnych numerów była zmienna, a średnio wynosiła 70 stron. Najwięcej, bo 96 stron liczyły numery 47 i 78, a najmniej - 38 stron - numer 2.

Numer ISSN (1732-4572) nadano „Teologii w Polsce” dopiero w 2004 r., wraz z ukazaniem się numeru 75, ale objął on także poprzednie zeszyty. Pismo nie miało ustalonej i podanej na okładce ceny; zapłatę w dowolnej kwocie należało przesyłać bezpośrednio na adres redakcji, np. listownie, ponieważ TwP nie miała własnego rachunku bankowego ${ }^{33}$. Aby uhonorować poszczególnych darczyńców, począwszy od numeru 42 z 1995 r. utworzono rubrykę „Damy i mężowie Opatrzności”, w której podawano nazwiska i nazwy instytucji wspierających pismo oraz przekazane przez nie kwoty.

\section{Struktura}

W całym analizowanym okresie $\mathrm{w}$ piśmie publikowano materiały zasadniczo odpowiadające podtytułowi „Dokumenty, Studia, Informacje”. W różnych okresach kolejność poszczególnych działów była jednak inna; czasami zdarzało się, że któryś pomijano, a w niektórych numerach wcale nie sygnalizowano przyjętego podziału w spisie treści, wpisując na pierwszej stronie frazę „W Numerze Między Innymi" (dotyczy to szczególnie lat dziewięćdziesiątych). Co więcej, aż do roku 2002 nie robiono tego w ogóle wewnątrz zeszytów; sytuacja zmieniła się dopiero w numerze 68/69, gdy - jak wspomniano wyżej - wprowadzono żywe paginy z nazwami działów.

W dziale „Dokumenty” zamieszczano raporty i sprawozdania (np. z zebrania Komitetu Nauk Teologicznych PAN), statuty jednostek KUL i innych organizacji (np. Ośrodka Archiwów, Bibliotek i Muzeów Kościelnych, Instytutu Jana Pawła II, Towarzystwa Naukowego KUL czy Stowarzyszenia Biblistów Polskich) oraz listy uhonorowanych Nagrodą im. Księdza Idziego Radziszewskiego. Zdarzały się tu również sprawozdania z działalności uniwersytetu przedrukowane z „Biuletynu Informacyjnego KUL” lub „Przeglądu Uniwersyteckiego”. Najwięcej materiałów tego rodzaju zamieszczano w początkowej fazie rozwoju pisma, w latach osiemdziesiątych; z czasem jednak pojawiały się coraz rzadziej i nieregularnie.

W dziale „Studia”, przemianowanym w 1988 r. na „Artykuły”, odnotowujemy w kolejnych latach wydawania pisma tendencję wzrostową. Publikowane tam teksty aspirowały do miana naukowych, jednak nie były opatrzone naukowym

${ }^{32}$ TwP, 16 (1998) nr 53. Ks. Władysław Łydka (1931-1987) - eklezjolog i mariolog, absolwent KUL (promotorem jego magisterium i doktoratu był ks. Wincenty Granat), wykładowca, a następnie rektor kieleckiego seminarium duchownego, referent sanktuariów maryjnych w diecezji kieleckiej i krótko wykładowca Akademii Teologii Katolickiej.

${ }^{33} \mathrm{~W}$ numerze 40 z 1995 r. redaktor naczelny napisał żartobliwie: „TwP nie ma konta, nie ma kasy, nie ma ceny, nie ma zysków...”. 
aparatem. Część z nich otwarcie przyjmowała charakter popularnonaukowy ${ }^{34}$. Przypisy pojawiają się w artykułach dopiero od numeru 79 z 2005 r., gdy pismo zaczęło obierać kurs na profil naukowy. Redakcja zachęcała do nadsyłania artykułów pocztą tradycyjną, a od 2004 r. - także elektroniczną.

Niezwykle rozbudowanym działem „Teologii w Polsce” były „Informacje”, przemianowane w 1990 r. na „Sprawozdania”. Miały one zbliżoną objętość przez cały okres wydawania pisma. Prezentowano tam aktualną sytuację w polskiej nauce teologicznej, informacje dotyczące sympozjów i zjazdów, sprawozdania (np. z Ogólnopolskiego Spotkania Ekumenicznego Teologów, Kongresów Eucharystycznych czy Dni Duszpasterstwa), relacje teologów z ich pracy w kraju i za granicą. Od numeru 8 z 1986 r. włączono do tego działu zawiadomienia o zatwierdzonych habilitacjach i doktoratach, najczęściej wraz z przedstawieniem sylwetki autora, autoreferatem oraz przedrukiem opinii promotora na temat pracy i uwag recenzentów. W dziale tym w ciągu dwudziestu lat przedstawiono ponad sto prac oraz sylwetek ich autorów. O. prof. Napiórkowskiemu zależało na tej rubryce szczególnie mocno, ponieważ wiele wartościowych dysertacji nie mogło się ukazać z powodu przeszkód natury finansowej. Chciał więc wydzielić dla nich miejsce w swoim piśmie. Według jego słów była to „piękna twórcza prowokacja, wołanie do promotora, by praca magisterska czy doktorska nie zaginęła $\mathrm{w}$ czeluściach archiwum" 35 .

Od numeru 34 z 1993 r. ze „Sprawozdań” w sposób wyraźny wyodrębniono strony, na których prezentowano nowości wydawnicze. Po raz pierwszy pełny spis treści przedstawianej publikacji zamieszczono już w 22 numerze „Teologii w Polsce” z 1990 r., a w numerze 26 gorąco zachęcano „kolegów-dogmatyków” do przekazywania informacji o swych książkach. Od numeru 27 z 1992 r. wiadomości o nowościach wydawniczych z dziedziny teologii były już nieodłącznym punktem niemal każdego zeszytu. Pod koniec lat dziewięćdziesiątych na informacje o nich przeznaczano od kilkunastu do kilkudziesięciu stron i tendencja ta utrzymała się aż do końca analizowanego okresu. Na łamach kwartalnika przedstawiano publikacje zarówno naukowców z KUL („Opublikowaliśmy”), jak i całej Polski („Opublikowali dla nas”). O. Stanisław Celestyn Napiórkowski w dowcipny i niebanalny sposób zachęcał naukowców, by przesyłali do redakcji swoje książki ${ }^{36}$. Można je było dzięki temu szerzej promować, a jednocześnie wy-

${ }^{34}$ Np. artykuły: J. Szymik, Teologia $w$ crainie pepsi-coli, TwP, 15 (1997) nr 49, s. 5; S.C. Napiórkowski, Uczymy się pisać teologiczne księgi, TwP, 15 (1997) nr 50, s. 42.

${ }^{35}$ Relacja Stanisława Celestyna Napiórkowskiego OFMConv z 18 kwietnia 2020 r.

${ }^{36}$ Od numeru 72 z 2003 r. zamieszczano w TwP następujący apel: „Koniecznie chcemy (ba, musimy) Cię zareklamować. Przyślij swoją książkę! Nasz Biuletyn informacyjny. Teologia w Polsce żyje po to, byśmy się lepiej znali, by kolega dogmatyk (przede wszystkim on, ale nie wyłącznie) informował kolegę dogmatyka (przed wszystkim jego, choć nie ekskluzywnie) o narodzinach swoich nowych ksiąg. Piszemy raczej sporo, publikujemy nieco mniej, jednak nie mało. Nie sposób wszystko śledzić, tym bardziej wszystko kupować, by reklamować. Pomóż się zareklamować. Nie chodzi ostatecznie o Ciebie (jeśli siostra pokora odradza Ci taką reklamę); chodzi o sprawę, w którą inwestujesz swoje życie. TwP bardzo chętnie poinformuje o Twoich publikacjach, ale zdarza się, że ich nie zauważa albo nie ma pieniążków na zakup... Przesyłajcie swoje publikacje, nie zapomnijcie 
pełniać informacyjną rolę periodyku. W czasach braku powszechnego dostępu do internetu stworzenie sprawnie działającego forum polskich teologów było bardzo cenną inicjatywą.

Prócz wyżej omówionych trzech działów, których nazwy umieszczone zostały w podtytule pisma, okazjonalnie pojawiały się także inne. Przykładowo, dział „Pomoce” pojawiał się cyklicznie, mniej więcej co pięć numerów, i zawierał najczęściej bibliografie przedmiotowe i podmiotowe ${ }^{37}$ oraz różne nowinki usprawniające warsztat teologa, np. informacje o możliwościach wykorzystania w pracy internetu ${ }^{38}$.

Od numeru 26 z 1991 r. funkcjonował na łamach pisma dział „Varia”, który wchłonął nieprzypisane dotą nigdzie listy czytelników, notatki i spostrzeżenia redaktora naczelnego, krótkie teksty, żarty słowne lub rysunkowe ${ }^{39}$, informacje o darowiznach w rubryce „Damy i Mężowie Opatrzności”. Właśnie w tym dziale najczęściej przejawiał się niepowtarzalny klimat pisma wykreowany przez o. Celestyna Napiórkowskiego. Choć pisał dla periodyku uniwersyteckiego, robił to niesztampowo i bardzo swobodnym językiem. Recenzje prac dyplomowych jego pióra były nierzadko osobiste z uwagi na więzi, jakie łączyły go z seminarzystami, którym poświęcał wiele uwagi i serca. Także odpowiedzi na publikowane w czasopiśmie listy były barwne i nasycone humorem. W piśmie ujawniła się nawet jego miłość do koni: zamieszczono dwie piękne grafiki z wierzchowca-

dopisać cenę. Redakcja TwP z pewnością nie odczyta jej jako apelu do własnego woreczka, ale jako dane interesujące Czytelników".

${ }^{37}$ Przykłady bibliografii: K. Klauza, Wykaz prac magisterskich i rozpraw licencjackich, doktorskich $i$ habilitacyjnych z teologii dogmatycznej obronionych na Wydziale Teologicznym KUL, TwP, 1 (1983) nr 1, s. 9-44; M. Słowik, Polska bibliografia nt. matzeństwa jako sakramentu, TwP, 6 (1988) nr 16, s. 56-67; H.I. Szumił, Teologiczna myśl Ks. Wincentego Granta. Bibliografia prac dyplomowych, TwP, 13 (1995) nr 44, s. 26-36; W. Siwak, Maryja w postudze i nauczaniu Jana Pawta II. Polska bibliografia przedmiotowa 1978-1986, TwP, 15 (1997) nr 49, s. 29-45; A. Bednarek, Kaznodziejstwo a literatura $w$ refleksji homiletycznej XIX $i$ XX w. (bibliografia adnotowana), TwP, 16 (1998) nr 52, s. 29-38; Spis publikacji ks. Andrzeja Zuberbiera, TwP, 18 (2000) nr 61, s. 46-55; B. Bernacki, K. Bernacka, Studia nad teologia polska i środkowoeuropejska. Bibliografia rozpraw habilitacyjnych i doktorskich oraz prac magisterskich i licencjackich powstałych na Wydziale Teologii Katolickiego Uniwersytet Lubelskiego (stan na 31.12.2000 r.), TwP, 20 (2002) nr 70, s. 26-37.

${ }^{38} \mathrm{P}$. Szelest, Internet $w$ warsztacie teologa, TwP, 19 (2001) $\mathrm{nr}$ 65, s. 56.

39 Żarty często dotyczyły profesorów prowadzących seminaria. Była to oznaka autoironii o. prof. Napiórkowskiego, ponieważ wśród studentów teologii KUL zwany był m.in. „Promotorem”. W dziale tym przytaczano też anegdoty z popularnej książeczki pod redakcją Giusy Bedettiego $R a-$ dość niedoskonała. Anegdoty ze świata chrześcijańskiego. Zamieszczane żarty mogły wydać się niekiedy kontrowersyjne, ale nadawały pismu swoisty koloryt. Jako przykład przytoczmy proroczy wic z numeru 57 z 1997 r.:

„Następny papież będzie Niemcem. Wiadomo nawet, jakie będą jego podstawowe encykliki (są w przygotowaniu; świetna organizacja pracy):

1. domatyczna: Gott mit uns

2. liturgiczna: Ordnung muss sein

3. misyjna: Drang nach Osten

4. ekumeniczna: Ein Reich, ein Volk, ein Führer

5. społeczna: Arbeit macht frei". 
mi. Znalazło się też miejsce dla zabawnej polemiki z właścicielką kota na temat zbawienia zwierzą ${ }^{40}$. Wydaje się, że to właśnie osobowość redaktora naczelnego sprawiała, że „Teologia w Polsce” była wyjątkowym fenomenem na polu ówczesnego czasopiśmiennictwa teologicznego w kraju. Wpływały na to niewątpliwie łatwość w nawiązywaniu kontaktów, otwartość na nowe środki we wzajemnym komunikowaniu się, dystans wobec egzaltowanej religijności, a także niekwestionowany autorytet naukowy. O. S.C. Napiórkowski przełamywał hermetyczność środowisk teologicznych, dopuszczając do głosu świeckich miłośników tej dyscypliny. Posiadł dar niekonwencjonalnego, pozbawionego moralizatorstwa sposobu postrzegania problemów nauki teologicznej oraz niebanalne możliwości ich rozwiązywania.

\section{Analiza treści}

Jak zaznaczono już wyżej, „Teologia w Polsce” stanowiła przede wszystkim forum, na którym prezentowano informacje o najnowszych wydarzeniach naukowych i publikacjach z dziedziny teologii. Oprócz tego publikowano tam artykuły luźno powiązane z tematyką naukową, jednak z pewnością inspirujące do dalszych poszukiwań. $Z$ biegiem lat charakter pisma stawał się coraz bardziej naukowy, a w 2007 r. nowa redakcja odrzuciła podtytuł wskazujący na charakter informacyjny i zdecydowała o przyjęciu wyłącznie naukowego profilu.

Zakres merytoryczny „Teologii w Polsce. Biuletynu Informacyjnego” obejmował przede wszystkim teologię dogmatyczną (w tym pneumatologię, mariologię, chrystologię, soteriologię i historię zbawienia) oraz ekumeniczną. Było to naturalną konsekwencją faktu, że pismo funkcjonowało pod auspicjami Sekcji Dogmatycznej Teologów Polskich, a badania w tym nurcie prowadził o. prof. S.C. Napiórkowski. Wyjątkowy był pod tym względem numer specjalny z $1987 \mathrm{r}$. Opublikowano tam thumaczenia artykułów na temat teologii środków przekazu społecznego pochodzących z prestiżowego fachowego pisma „La Civiltà Cattolica" związanego ze Stolicą Apostolską. Poza numerami specjalnymi, które wymieniono wyżej, zdarzały się także numery tematyczne - szczególnie w dwóch pierwszych dekadach istnienia pisma. Odnotujemy tu numery: 4 z 1984 r. (opisujący Wyższe Seminarium Duchowne w Pelplinie oraz Sympozjum Sekcji Dogmatycznej Teologów Polskich zorganizowane tam 17-18 września 1984 r.), 9 z 1986 r. (poświęcony sympozjum mariologicznemu na KUL), 13 z 1987 (z tematem wiodącym pt. Drogi odnowy kultu maryjnego wedlug adhortacji Pawta VI „Marialia Cultus”), 14 z 1987 r. i 15 z 1988 r. (w całości wypełnione referatami z Sympozjum Sekcji Dogmatycznej Teologów Polskich w Ołtarzewie, 15-16 października 1987 r. „Świeccy w Kościele polskim”), 41 z 1995 r. (z materiałami z sympozjum Sekcji Dogmatycznej Teologów Polskich pt. „Zbawienie w Kościele i przez Kościół”, które odbyło się 23-24 września 1994 r.), 50 z 1997 r. (zawierający teksty nt. spraw wschodnich, np. relacje z Berdyczowa, Moskwy, Rostowa nad Donem czy informację o wydaniu pamiętników Zofii Szeptyckiej) oraz 56

${ }^{40}$ S.C. Napiórkowski, Do Joli w sprawie kota, TwP, 14 (1996) nr 47, s. 70. 
z 1999 r. (z materiałami z Tygodni Eklezjologicznych z dwóch poprzednich lat organizowanych przez Koło Naukowe Teologów KUL).

Głównym źródłem inspiracji dla twórców pisma były aktualne tematy podejmowane na forum światowej teologii. Szczególnie fascynujący był nurt tzw. nowej teologii, często przywoływano też twórczość wybitnych teologów - ks. Karla Rahnera SJ i ks. Hansa Ursa von Balthasara. Oprócz odwołań do globalnych trendów $\mathrm{w}$ badaniach teologicznych, opisywano dokonania środowisk lubelskiego i ogólnopolskiego. Wiele informacji publikowanych w biuletynie odnosiło się do franciszkanów, co było związane z faktem, że czarny habit braci mniejszych nosił także redaktor naczelny ${ }^{41}$.

\section{Podsumowanie}

Pismo „Teologia w Polsce. Biuletyn Informacyjny. Dokumenty, Studia, Informacje" ukazywało się w latach 1983-2006, początkowo nieregularnie, a od $1990 \mathrm{r}$. jako kwartalnik. W tym czasie nieprzerwanie redagował je o. prof. Stanisław Celestyn Napiórkowski OFMConv, wraz ze zmieniającymi się współpracownikami. Ukazało się 86 numerów pisma, a zamieszczane treści były zgodne z jego informacyjną misją: dominowały sprawozdania, raporty, statuty, przedruki autoreferatów teologicznych prac doktorskich z uwagami recenzentów, a także relacje ze zjazdów i konferencji. Artykuły naukowe i popularnonaukowe dotyczyły aktualnych tematów z teologii systematycznej i ekumenicznej.

W założeniu redakcji czasopismo miało pełnić w ogólnopolskim środowisku teologicznym funkcję komunikatora i informatora. Publikowane w nim treści kierowane były zarówno do duchownych, jak i świeckich, do osób zawodowo zajmujących się teologią oraz absolwentów tego kierunku, którzy wybrali inny sposób zarobkowania. 71\% autorów miało bezpośrednie związki z KUL, przy czym w piśmie ukazywały się również teksty wybitnych postaci nauki teologicznej $\mathrm{z}$ innych ośrodków akademickich.

W 2007 r. nowa redakcja ${ }^{42}$ zmieniła profil czasopisma, format i szatę graficzną. Postanowiono także, że nie będzie już ono kwartalnikiem, ale półrocznikiem. Ponieważ publikuje się w nim od tego czasu wyłącznie recenzowane artykuły naukowe z teologii systematycznej - częstokroć w językach obcych - odstąpiono od drugiego członu nazwy: „Biuletyn Informacyjny”. Czasopismo „Teologia w Polsce" zachowało jednak ciągłość, o czym świadczy niezmieniony numer ISSN. Pierwsza odsłona nowej serii ukazała się pod koniec 2007 r. pod numerem $1[85]^{43}$.

${ }^{41} \mathrm{~Np}$. artykuły pt. O studiach franciszkanów w Polsce, TwP, 4 (1986) nr 7, s. 31-41; Instytut studiów franciszkańskich, TwP, 17 (1999) nr 57, s. 9-16.

${ }^{42}$ Ks. Krzysztof Góźdź - redaktor naczelny, ks. Grzegorz Strzelczyk - redaktor prowadzący, Karol Klauza - sekretarz redakcji.

${ }^{43}$ Powinno być: [87]. 
Przekazanie pisma było skutkiem naturalnej wymiany pokoleń w polskiej nauce teologicznej. Żegnający się z czytelnikami o. Celestyn Napiórkowski thumaczył w ostatnim numerze:

Powstała nowa sytuacja: - Sekcja Dogmatyczna Teologów Polskich przeobraża się w Towarzystwo. Biorąc to pod uwagę, uwzględniając także liczbę wiosen pielgrzymowania po tym pięknym świecie, mając też na oku kilka rozpoczętych poważnych akcji, które chciałoby się zdążyć doprowadzić do końca, zgłosiłem swoją decyzję przekazania młodszym ojcowania naszemu „Biuletynowi Teologia w Polsce", co Olimp nowonarodzonego Towarzystwa przyjął ze zrozumieniem. Przy okazji podejmie próbę edytorskiej promocji kwartalnika, zachowując zasadniczą jego linię. [...] Biuletyn informował, wprowadzając szczyptę rodzinności. Liczne zaniedbania i potknięcia - spróbujcie wybaczyć, jeśli to możliwe. Dzięki za współpracę i dobre słowa. Damom i Mężom Opatrzności - gratias! ${ }^{44}$

\section{REFERENCES / BIBLIOGRAFIA}

\section{Źródła}

Archiwum Uniwersyteckie KUL

zespoły: Referat Personalny, Akta osobowe studentów.

„Teologia w Polsce. Biuletyn Informacyjny”, 1-24 (1983-2006) nr 1-85/86.

\section{Relacje}

Relacja o. Stanisława Celestyna Napiórkowskiego OFM Conv z 18 kwietnia 2020 r.

Relacja Karola Klauzy z 17 kwietnia 2020 r.

Relacja Adama Jarząbka z 16 kwietnia 2020 r.

Relacja Anny Faszczowej z 20 kwietnia 2020 r.

\section{Opracowania}

Fijołek M., ,, Teologia w Polsce”, w: Encyklopedia 100-lecia KUL, t. 2, red. E. Gigilewicz, Lublin 2018, s. 471-472.

\footnotetext{
${ }^{44}$ TwP, 24 (2006) nr 85/86, s. 80.
} 


\title{
"A SOURCE OF INFORMATION WITH A HINT OF FAMILIAL WARMTH". "TEOLOGIA W POLSCE. BIULETYN INFORMACYJ- NY. DOKUMENTY, STUDIA, INFORMACJE" - MAGAZINE REVIEW (1983-2006)
}

\begin{abstract}
The „Teologia w Polsce. Biuletyn Informacyjny. Dokumenty, Studia, Informacje" journal was published over the years 1983-2006 at the discretion of Father Stanisław Celestyn Napiórkowski OFMConv and Karol Klauza. During that period, it provided a platform for information and communication for the graduates of the Faculty of Theology of the Catholic University of Lublin and their lecturers, and subsequently for Polish theologians in general. The article attempts to trace the history of the magazine's origin and functioning, describe its structure, and analyse the content of its individual issues.
\end{abstract}

Keywords: „Teologia w Polsce”; theology; magazine; Stanisław Celestyn Napiórkowski; Karol Klauza; Faculty of Theology; Catholic University of Lublin 